\title{
Entomopathogenic microorganisms in locusts and grasshoppers populations and prospects for their use for control of this pest group
}

\author{
Georgiy Lednev*, Maxim Levchenko, and Igor Kazartsev \\ All-Russian Institute of Plant Protection, Podbelskogo 3, 196608, St. Petersburg, Pushkin, Russia
}

\begin{abstract}
Brief information on the main groups of microorganisms parasitizing on locusts and grasshoppers is given. It has been shown that viral and most bacterial infections have no practical prospects, both as natural regulators of density populations and as potential producers of bioinsecticides. Alpha-proteobacteria, entomophthoralean fungi and microsporidia may make some contributions as natural mechanisms of population dynamics. The most significant group as producers of biopesticides are anamorphic ascomycetes from the genera Metarhizium and Beauveria.
\end{abstract}

\section{Introduction}

Members of the family Acrididae, and especially locusts are one of the most harmful groups of phytophages. Locusts usually increase their number in natural environments where their monitoring is complicated and application of chemical insecticides is impossible (e.g. nature protection areas), or cannot be justified on economic or ecological basis $[1,2,3]$. A locust outbreak is an emergency situation and removal of its consequences requires considerable financial and material resources.

At present in the former USSR only chemical insecticides are used for the control of locust populations [4]. However, it is known that large-scale pesticide application has a number of essential shortcomings, the most important are appearance of resistant populations of pests and environmental pollution. In this regard there is a need in alternative ecologically safe methods for plants protection. One of them is suppression of phytophages with biological products based on entomopathogenic microorganisms (viruses, bacteria, fungi). Besides, information about degree of natural infection with entomopathogens in locust populations can be useful in terms of pest outbreak prediction and planning of insecticides applications.

The purpose of this work is to review the main pathogens of locust and the prospects of their use.

\footnotetext{
* Corresponding author: georgijled@mail.ru
} 


\section{The main pathogens of locusts and grasshoppers}

\subsection{Viruses}

The only RNA-containing entomopathogenic virus found in locust populations belongs to cytoplasmic polyhedrosis virus (family Reoviridae) [5]. It was first found in Caledia capetiva (Fabr.) and increased migratory locust mortality due to bacteriosis caused by Enterobacter cloacae (Jord.) Horm. and Edw. Among the DNA-containing viruses, an entomopoxvirus [6] and iridescent virus were revealed [7]. The former virus infected adipose cells of Anacridium aegiptium L., while the latter second was isolated from crickets and showed ability to infect desert and migratory locusts. These pathogens, however, do not tend to cause epizootics and can be considered as potential biocontrol agents only in theory [1]. Investigation of natural incidence of viruses in locust populations is not of practical interest as well as they meet extremely seldom.

\subsection{Bacteria}

A particular interest in the last decades is attracted by alphaproteobacteria from the genus Wolbachia and mycoplasma from the genus Spiroplasma. The studies of Wolbachia in locust populations are focused on grasshoppers, mainly from the genus Chorthippus [8, 9]. It is supposed that presence of this endocytobiont leads to genetic isolation of host populations [10]. Potential impact of Wolbachia on processes of hybridization in the overlapping areas of insect host subspecies is noted and horizontal transfer of genes from a genome of a parasite in the host's genome is proved [11, 12]. Changes in incidence dynamics of Wolbachia during the life cycle of grasshoppers may be connected with weather conditions [13]. It was discovered that conjoint infection of Chorthippus parallelus Zett. by Wolbachia and Spiroplasma, induces insect cytoplasmatic incompatibility with the dominating role of the first symbiont [8]. Practically nothing is known about endocytobionts of locusts, though these pathogens can affect the structure of locust populations and therefore define abundance dynamics that may be useful in predictions.

Bacillus thuringiensis Berl. is of the greatest interest in terms of development of bioinsecticides among bacteria. On its basis the majority of biological products was developed for Lepidoptera, Coleoptera and Diptera control, however, the knowledge of active $B$. thuringiensis strains is limited $[1,14]$.

Only a few bacterial species are known as locust parasites. Enterobacter cloacae, Serratia marcescens Bizio, S. entomophila Grim and Pseudomonas aeruginosa (Schr.) Mig. are most known, but because of low specificity unsuitable for biological control $[1,15]$.

\subsection{Fungi}

About 15-20 species of micromycetes are associated with Acridoidea. In terms of natural density regulation, the entomophthoralean fungi Entomophaga grylli (Fres.) Batko (=Entomophthora grylli Fres.) (Entomophthoromycota: Entomophthorales) is of the greatest interest. This species infects members of various families of Orthoptera, (Tettigoniidae, Gryllidae, Acrididae, etc.). The disease caused by this fungal species is the most common in Acrididae, both locusts, and grasshoppers; including such harmful types as Calliptamus italicus L., Locusta migratoria L. and Dociostaurus marrocanus Thunb. (locusts), Gomphocerus sibiricus L., Oedipoda caerulescens L. (grasshoppers) [16]. E. 
grylli is considered to be a species complex including considerable number of the various pathotypes differing by morphology and parasitic properties, including host range. Bidochka with coauthors [17] showed that pathotype III from Australia, referred to as E. praxibulli, has a wider range of hosts and demonstrate higher virulence as compared to North American pathotypes. The attempt of this pathotype introduction was carried out in the US, however it was not successful. E. grylli is capable of causing a periodic epizootics in host populations across all continents, serving as one of the most important mechanisms of density dynamics $[18,19]$. In particular, entomophthoralean outbreaks in C. italicus were reported [20]. This fungus is difficult to isolate and culture in vitro; it grows slowly on artificial media, does not produce conidia and tends to lose activity [21]. In this regard, it is of no interest in terms of development of biological products, however its natural incidence requires monitoring.

Among anamorphic fungi, members from genera Beauveria, Metarhizium, Isaria, Hirsutella, Lecanicillium, Aspergillus, etc. were detected in locusts [22-26].

Members of these genera are found sporadically in locust populations though local foci are being occasionally observed [27]. At the same time, many experts draw attention to development of antilocust mycoinsecticides. Special attention is paid to Beauveria and Metarhizium genera [1, 28] currently. As many as 11 formulations are applied for locust control on the basis of entomopathogenic fungi [29]. Green Muscle and Green Guard on the basis of Metarhizium acridum (Driv.\&Miln.) Bisch., Rehn. \& Humb. are the most popular formulations. Recently, antilocust mycoinsecticides Mycolar B (Beauveria bassiana (Bals.Criv.) Vuill.) and Mycolar M (Metarhizium anisopliae (Metschn.) Sorok.) have been developed by All-Russian Institute of Plant Protection in collaboration with colleagues from Kazakhstan. These formulations have high efficiency in arid zones [30].

\subsection{Microsporidia}

In Orthoptera 18 species of microsporidia were described [31-33] from various phylogenetic lines. Microsporidia possess the ability to suppress immunity of insects hosts [34-36] and to increase susceptibility of the infected insects to chemical [37] and biological plant protection products [38]. In a number of studies, synergistic interactions between entomopathogenic fungi and microsporidia were shown during simultaneous infection of locusts and grasshoppers under laboratory and field conditions [39].

Paranosema locustae Cann. is the only microsporidia which was registered for grasshopper biocontrol purposes and produced in the USA since 1980s by a variety of companies and marketed under trade names such as Nolo Bait ${ }^{\mathrm{TM}}$, Semaspore ${ }^{\mathrm{TM}}$, and Grasshopper Attack ${ }^{\mathrm{TM}}$ [4].

For this species long-term (over 10 years) persistence since introduction in local populations of solitarious locust in Argentina [41] was shown.

In recent years in Russia intensive researches on technology optimization of mass cultivation are conducted [41].

\section{Conclusion}

It can be concluded that viruses and most bacteria have no practical prospects and as natural regulators of locust abundance and as potential producers of bioinsecticides. Alphaproteobacteria, entomophthoralean fungi and microsporidia can play a key role as mechanisms of locust population dynamics regulator. The most significant fungi for biopesticides production is presented by species from anamorphic genera Metarhizium and Beauveria. 
The work was supported by the Russian Foundation of Basic Research, project № 20016-00263.

\section{References}

1. C.J. Lomer, R.P. Bateman, D.L.Johnson, J. Langewald, M.B. Thomas, Ann, Review Entomol. 46, 667-702 (2001)

2. V.I. Dolzhenko, Harmful locusts: biology, tools and control technology. 216 (2003) (in Russ.)

3. L. Zhang, M. Lecoq, A. Latchininsky, D. Hunter Annu Rev Entomol. 64, 15-34 (2019)

4. G.I. Sukhoruchenko, L.A. Burkova, G.P. Ivanova, T.I. Vasilyeva, O.V.Dolzhenko, S.G. Ivanov, V.I. Dolzhenko, Plant Protection News, 1(103), 05-24 (2020) (in Russ.)

5. D.A. Colgan, Bull. Entomol. Res. 76, 539-544 (1986)

6. J.J. Lipa, P. Hernandez-Crespo, J. A. Gonzalez-Reyes, C. Santiago, Biocontrol Sci Technol. 4, 343-345 (1994)

7. R.G. Kleespies, C. Tidona, G. Darai, J. Invertebr. Pathol. 73(1), 84-90 (1999)

8. P. Martínez-Rodríguez, M. Hernández-Pérez, J.L.Bella, Microb Ecol. 66(1), 211-23 (2013)

9. P. Martínez-Rodríguez, E. Rolán-Alvarez, M. Del Mar Pérez-Ruiz, F. ArroyoYebras, C. Carpena-Catoira, A. Carvajal-Rodríguez, J.L. Bella, Microb Ecol. 77(4), 10361047 (2019)

10. J.L. Bella, P. Martínez-Rodríguez, F.Arroyo-Yebras, A. Bernal, J. Sarasa, B. Fernández-Calvín, P.L. Mason, M. Zabal-Aguirre, J. Orthopt. Res. 19(2), 205-212 (2010)

11. L.J. Funkhouser-Jones, S.R. Sehnert, P. Martínez-Rodríguez, R. Toribio-Fernández, M. Pita, J.L. Bella, S.R. Bordenstein, PeerJ. 7, e1479 (2015)

12. R. Toribio-Fernández, J.L. Bella, P. Martínez-Rodríguez, L.J. Funkhouser-Jones, S.R. Bordenstein, M. Pita, Chromosome Res. 25(3-4), 215-225 (2017)

13. P. Martínez-Rodríguez, R. Granero-Belinchón, F. Arroyo-Yebras, J.L. Bella, Bull. Math. Biol. 76(10), 2646-2663 (2014)

14. B. Zelazny, M.S. Goettel, B. Keller, The Memoirs of the Entomological Society of Canada, 129, 147-156 (1997)

15. T.A. Mashtoly, M.S. El-Zemaity, A. Abolmaaty, G.M. Abdelatef, A.A. Marzouk, M. Reda, Egypt. J. Biol. Pest. Control. 29, 1-9 (2019)

16. E.Z. Koval, Fungi flora of Ukraine. Zygomycetes. Entomophthora fungi. 369 (2007) (in Russ.)

17. M.J. Bidochka, G.G. Khachatourians, Exp. Mycol. 12, 161-168 (1988)

18. A.V. Latchininsky, I.I. Temreshev, M.K. Childebaev, S.V. Kolov, J. Orthoptera Res. 25(2), 83-89 (2016)

19. L. Zhang, P. Zhang, L. Zhang, Biocontrol Sci Technol. 28(159), 1-10 (2018)

20. A. B. Batko, Collection of student scientific works of Moscow State University. 7479 (1957)

21. M. Gustafsson, Landbr'hogsk. Annl. 31, 103-212 (1965)

22. A. A. Evlakhova, Entomopathogenic fungi. Systematics, biology, practical significance, 260 (1974) (in Russ.)

23. B.N. Ogarkov, G.R. Ogarkova, Entomopathogenic fungi of Eastern Siberia, 2000, 134 (2000) (in Russ.)

24. S.N. Wood, M.B. Thomas, Proceed. Royal Soc. London, 263, 673 - 680 (1996)

25. G.R. Lednev, B.A. Borisov, G.V. Mitina, Mycosis of insects. 79 (2003) (in Russ.)

26. I.I. Temreshev, Author. dis. Candidate of Biological Sciences.23 (2003) (in Russ.) 
27. G.R. Lednev, M.V. Levchenko, Plants protection from pests and diseases. Tr. SPbGAU, 5762 (2004) (in Russ.)

28. G.R. Lednev, M.V. Levchenko, V.Yu. Kryukov, P.V. Mitkovets, O.N. Yaroslavtseva, A.M. Uspanov, V.A. Pavlyushin, Plant Protection and Quarantine. 6, 18-21 (2012) (in Russ.)

29. M. Faria, S.P. Wraight, Biol. Control. 43, 237-256 (2007)

30. G.R. Lednev, M.V. Levchenko, A.M. Uspanov, A.O. Sagitov, V.A. Pavlyushin, Modern technologies and plant protection products - a platform for innovative development in the agricultural sector of Russia 95-97 (2018) (in Russ.)

31. Y.Y. Sokolova, C.E. Lange, J.R. Fuxa, J. Invertebr. Pathol. 3, 168-182 (2006)

32. I.V. Issi, Y.S. Tokarev, E.V. Seliverstova, E.S. Nassonova, Acta Protozool. 2, $125-$ 133 (2008) (in Russ.)

33. A.N. Ignatieva, A.V. Gerus, I.V. Senderskiy, S.M. Malysh, V.I. Dolzhenko, Y.S. Tokarev, J. Eukaryot. Microbiol. 4, 680-683(2019)

34. Ya.L. Vorontsova, Yu.S. Tokarev, Yu.Ya. Sokolova, V.V. Glupov, Parasitology, 3. 239 (2004) (in Russ.)

35. I.V. Issy, V.V. Dolgikh, Yu.Ya. Sokolova, Yu.S. Tokarev, Agricultural Science, 3, $17(2005)$

36. Y.S. Tokarev, Y.Y. Sokolova, R. Entzeroth, J. Invertebr. Pathol. 1, 70-73 (2007)

37. D.L. Johnson, J.E. Henry, J. Econ. Entomol. 80, 685-689 (1987)

38. M. O. Bauer, J. D. Nascimento, A. J. Regazzi, E. A. M. Silva, Rev. Bras. Zootec. 27(1), 1-8(1998)

39. Y.S. Tokarev, M.V. Levchenko, A.M. Naumov, I.V. Senderskiy, G.R. Lednev, J. Invertebr. Pathol. 2, 336-338 (2011)

40. J. E. Henry, Protistology, 3, 175-182 (2017)

41. 14. C. E. Lange, F. G. Azzaro, J. Invertebr. Pathol. 3 357-359 (2008)

42. A.V. Gerus, I.V. Sendersky, M.V. Levchenko, T.Yu. Zakota, Yu.S. Tokarev, Plant Protection News, 3(89), 48-50 (2016) 